\title{
Optimization of the Production of a Honeybee Odorant-Binding Protein by Pichia pastoris
}

\author{
Loïc Briand,* Valérie Perez,* J ean-Claude Huet,* Emmanuelle Danty, ${ }^{*} \ddagger$ \\ Claudine Masson, $\dagger \ddagger$ and J ean-Claude Pernollet*,1 \\ *U nité de Recherches de Biochimie et Structure des Proténes, INRA UR 477, Domaine de Vilvert, F-78352, \\ J ouy-en-J osas Cedex, France; †N eurobi ol ogi e Expérimentale et Théorie des Systèmes Complexes, \\ CNRS UPR 9081, 16, rue Claude Bernard, F-75231 Paris Cedex 05, France; and ¥Centre \\ Européen des Sciences du Goût CNRS, 15, rue H. Picardet, 21000 Dijon, France
}

Received November 2, 1998, and in revised form December 18, 1998

\begin{abstract}
A honeybee putative general odorant-binding protein ASP2 has been expressed in the methylotrophic yeast Pichia pastoris. It was secreted into the buffered minimal medium using either the $\alpha$-factor preprosequence with and without the Glu-Ala-Glu-Ala spacer peptide of Saccharomyces cerevisiae or its native signal peptide. Whereas ASP2 secreted using the $\alpha$-factor preprosequence with the spacer peptide showed $\mathrm{N}$-terminal heterogeneity, the recombinant protein using the two other secretion peptides was correctly processed. Mass spectrometry showed that the protein secreted using the natural peptide sequence had a mass of $13,695.1 \mathrm{Da}$, in perfect agreement with the measured molecular mass of the native protein. These data showed a native-like processing and the three disulfide bridges formation confirmed by sulfhydryl titration analysis. After dialysis, the recombinant protein was purified by one-step anion-exchange chromatography in a highly pure form. The final expression yield after 7-day fermentation was approximately $150 \mathrm{mg} / \mathrm{iter}$. To our knowledge, this is the first report of the use of a natural insect leader sequence for secretion with correct processing in P. pastoris. The overproduction of recombinant ASP2 should allow ligand binding and mutational analysis to understand the relationships between structure and biological function of the protein. $\odot 1999$ Academic Press
\end{abstract}

In vertebrates, odorant-binding proteins (OBPs) ${ }^{2}$ are soluble, low-molecular-weight proteins secreted by dif-

\footnotetext{
${ }^{1}$ To whom correspondence should be addressed. Fax: 331346527 65. E-mail: pernolle@jouy.inra.fr.

${ }^{2}$ Abbreviations used: AOX1, gene encoding AOXI alcohol oxidase; ASP2, honeybee antennal-specific protein; BMGY, buffered minimal glycerol medium; BMM, buffered minimal methanol; GOBP, general odorant-binding protein; HIS4, gene encoding HIS4 histidinol dehy-
}

ferent nasal glands into the olfactory mucus. These very abundant proteins are involved in perception of odorants (1-3). Although their functions are still unclear, OBPs are thought to be involved in the solubilization, transport, and/or deactivation of odorants (4). In insect antennae, soluble proteins, distributed in the sensillum lymph surrounding the dendrites of ol factory sensilla, showed similar biochemical properties (5). Insect OBPs are classified as pheromone-binding proteins (PBPs) and general odorant-binding proteins (GOBPs). While PBPs are involved in sex pheromone detection, GOBPs seem to play a more general role in olfaction (6). However, to date, only one study has described the binding properties of insect GOBPs (7). Recently, a putative GOBP, called ASP2 for antennalspecific protein, specifically expressed in olfactory antennal tissues of the honeybee, Apis mellifera L., has been purified, characterized and cloned (8). ASP2 is a nonglycosylated protein of 13,695.2 $\pm 1.6 \mathrm{Da}$ (calculated 13,694.8) with three disulfide bridges and a calculated isoelectric point of 4.8. Its higher expression level in the antennae of workers than in drones suggests some involvement in general odorant detection (9). To study the biological properties and functions of ASP 2 in olfaction, a ready supply of protein is required and therefore attempts to develop an expression sys-

drogenase; HPLC, high-performance liquid chromatography; IS-MS, ion spray-mass spectrometry; KEX2, gene encoding Kex2 protease; MD, minimal dextrose medium; $M M$, minimal methanol medium; Mut $^{\text {s }}$, methanol utilization slow; OBP, odorant-binding protein; PBP, pheromone-binding protein; PCR, polymerase chain reaction; $\mathrm{PHOI}$, gene encoding $\mathrm{PHOI}$ acid phosphatase; QAE, quaternary amino ethyl; RDB, regeneration dextrose medium; SDS-PAGE, sodium dodecyl sulfate-polyacrylamide gel electrophoresis; STE13, gene encoding Stel3 protease; YNB, yeast nitrogen base with ammonium sulfate without amino acids. 
tem have been made. Bacterial expression systems have often failed to produce high yields of properly folded cystine-rich proteins such as PBPs. Nevertheless, with three PBPs, approximately $5 \%$ of the proteins expressed in bacteria could be obtained in soluble forms, purified and characterized as functionally active (10). Moreover, PBPs expressed in inclusion bodies have been successfully solubilized, refolded into their pheromone-binding native forms $(7,11,12)$. PBP from the male silkmoth Antheraea pernyi has been also expressed by baculovirus-infected insect cells but leading to a low level of secreted protein (13).

The Pichia pastoris yeast expression system provides an excellent alternative and has been successfully used to produce large quantities of disulfidebonded proteins $(14,15)$. Secretion is the best mode of protein production since the organism secretes only very low levels of its own proteins which facilitates protein purification. The secreted protein requires the presence of a signal sequence to target it into the secretory pathway. The $P$. pastoris acid phosphatase (PHOI) secretion signal is not preferred since, after secretion, it leaves an amino acid (Arg) at the $\mathrm{N}$-terminus of the recombinant protein. Two recent studies concerning the recombinant $\beta$-cryptogein and the synthetic monocyte chemoattractant protein 1 showed that the presence of an extra Arg at the $\mathrm{N}$-terminus or the lack of the first two amino acids of the protein could significantly change its biological activity $(16,17)$. The 89 amino acid secretion signal sequence from Saccharomyces cerevisiae $\alpha$-factor prepropeptide has been used with the most success (18) such as, for instance, aprotinin (19), mouse epidermal growth factor (20), thrombomodulin fragment, blood factor XII (14), a fragment of amyloid $\beta$-protein (21), antibody singlechain Fv fragment (22), N-lobe of human serum transferrin (23), human interleukin-17 (24), hirudin (25), and anticoagulant-antimetastatic protein ghilanten (26). However, even with this signal peptide, aberrant processing has been observed $(27,28)$.

As an alternative, the native signal from different organisms has also been used successfully for heterologous protein expression in P. pastoris (29-34). In this paper, we examined the impact of the S. cerevisiae $\alpha$-factor preprosequence with and without the Glu-Ala repeats or the insect signal peptide on the secretion of properly processed and folded ASP2 into a minimum buffered salt medium. The purification and the biochemical characterization of the recombinant protein ASP2 are also described.

\section{MATERIALS AND METHODS}

\section{Materials}

The pHIL-D2 and pPIC9 shuttle vectors and P. pastoris strain GS115 (his4 ${ }^{-}$) were from Invitrogen (The
Netherlands). Media components were purchased from Difco (Serlabo, France). Escherichia coli strain $\mathrm{DH} 5 \alpha$ was used for DNA subcloning. Restriction endonucleases were purchased from Eurogentec (Belgium). All other reagents were obtained from Sigma (France). ASP2 CDNA clone O12.7 (8) was used as the template for polymerase chain reaction (PCR).

\section{Construction of Expression Vectors}

The following different expression constructs were made as outlined in Fig. 1.

(a) The CDNA encoding the mature ASP2 without its native signal peptide was amplified by PCR using the following primers: 5' primer, 5'-TGTCTGCTACTCGAGAAAAGAGAGGCTGAAGCTATAGATCAAGACACCGTAGTC-3'; 3' primer, 5'-ATACGTGAATTCTTACGAGAACAGTTTCTCGAT-3' and the ASP2 CDNA clone O12.7 as the template. The PCR-amplified fragment was cloned into the Xhol and EcoRI sites of PPIC9, generating the construct with the full preprosequence pEAEA $\alpha A S P 2$. In this construct, two Glu-Ala repeats have been introduced between the $\alpha$-factor mating prepropeptide and the mature ASP 2 sequence.

(b) The 5' primer used in the first construct was replaced with the 5' primer, 5'-GGATCGCTCGAGAAAAGAATAGATCAAGACACC-3' to delete the two GluAla repeats between the $\alpha$-factor secretion peptide and the mature ASP2 sequence. The PCR-amplified fragment was cloned into the Xhol and EcoRI sites of pPIC9, generating the construct $\mathrm{p} \alpha \mathrm{ASP} 2$.

(c) In the last construction pNatASP2, the cDNA encoding the native precursor ASP 2 was amplified by PCR using the following primers:the $3^{\prime}$ primer used in the first two constructs and the 5' primer, 5'-CAACTTGAATTCACCATGAACACCCTCGTCACC-3' allowing the creation of a Kozak consensus sequence and the restriction sites. The PCR-amplified fragment was cloned into the EcoRI site of pHIL-D2 (previously cleaved by EcoRI and treated with calf intestinal phosphatase to reduce self-ligation). The correct orientation of the DNA insert was determined by PCR using the 5' AOX1 primer from Invitrogen and the $3^{\prime}$ primer described in (a).

\section{DNA Sequencing}

The dideoxy chain termination method of DNA se quencing was carried-out on double-stranded DNA plasmids with BigDye terminators (Applied Biosystems, France) on a PCR apparatus (DNA thermal cycler 480, Perkin-Elmer, France). The PCR products were analyzed on an automatic sequencer (ABI PRISM 310, Applied Biosystems). 


\section{Transformation of $\mathrm{P}$. pastoris}

Yeast transformation was performed using a spheroplasting method as described in the manual (Version 3.0) of the Pichia expression kit (Invitrogen). For transformation, the plasmids pEAEA $\alpha$ ASP 2 and $\mathrm{p} \alpha \mathrm{ASP} 2$ were digested with Bglll and pNatASP2 with $\mathrm{Notl}$. After 4- 6 days of incubation at $29^{\circ} \mathrm{C}$ on RDB medium (1 $\mathrm{M}$ sorbitol, $2 \% \mathrm{w} / \mathrm{V}$ D-glucose, $1.34 \% \mathrm{w} / \mathrm{V}$ YNB, 4 $\mu \mathrm{g} / \mathrm{ml}$ D-biotin, $0.005 \% \mathrm{v} / \mathrm{v}$ amino acids without histidine), isolated colonies were streaked onto MM $(0.5 \%$ $\mathrm{v} / \mathrm{v}$ methanol, $1.34 \mathrm{w} / \mathrm{v} \mathrm{YNB}, 4 \mu \mathrm{g} / \mathrm{ml} \mathrm{D}-$ biotin) and MD ( $2 \% \mathrm{w} / \mathrm{v}$ D-glucose, $1.34 \% \mathrm{w} / \mathrm{v}$ YNB, $4 \mu \mathrm{g} / \mathrm{ml}$ D-biotin) agar plates. After 2 days, Mut ${ }^{\mathrm{s}}$ transformants (slow growth on methanol as a sole carbon source) were retained for further study.

\section{Selection of Secreting Clones}

$\mathrm{His}^{+} \mathrm{Mut}^{\mathrm{S}}$ transformants were inoculated in $10 \mathrm{ml}$ of BMGY medium (1\% w/v yeast extract, $2 \% \mathrm{w} / \mathrm{v}$ peptone, $1.34 \% \mathrm{w} / \mathrm{v}$ YNB, $4 \mu \mathrm{g} / \mathrm{ml}$ D-biotin, $100 \mathrm{mM}$ potassium phosphate, $\mathrm{pH} 6.0,1 \% \mathrm{v} / \mathrm{v}$ glycerol) in sterile $50 \mathrm{ml}$ Erlenmeyer flasks which were then incubated at $29^{\circ} \mathrm{C}$, 300 rpm for 2 days. Induction of protein expression was achieved by harvesting the cells by centrifugation at $3000 \mathrm{~g}$ for $5 \mathrm{~min}$ at room temperature and resuspending them in $2 \mathrm{ml}$ of BMM medium (1.34\% w/v Y NB, $4 \mu \mathrm{g} / \mathrm{ml}$ D-biotin, $100 \mathrm{mM}$ potassium phosphate, $\mathrm{pH} 6.0,0.5 \%$ $\mathrm{v} / \mathrm{v}$ methanol) before continuing the incubation as earlier. After 2 days, samples were centrifuged at 12,000g for $10 \mathrm{~min}$ at room temperature to pellet the cells and $100 \mu \mathrm{l}$ of the supernatant was removed for analysis by automated HPLC on a HP1090M device (HewlettPackard, France). Recombinant ASP 2 was analyzed by reversed-phase HPLC on a Aquapore (C8) RP 300 column $(0.21$ i.d. $\times 3 \mathrm{~cm}$, Brownlee, Perkin-Elmer, France) equilibrated with solvent $\mathrm{A}\left(0.1 \%\right.$ TFA in $\left.\mathrm{H}_{2} \mathrm{O}\right)$ and eluted with a linear gradient up to $60 \%$ solvent $B$ (95\% acetonitrile, $5 \% \mathrm{H}_{2} \mathrm{O}, 0.085 \%$ TFA) for $30 \mathrm{~min}$. The temperature of the column was maintained at $40^{\circ} \mathrm{C}$. The flow rate was $0.2 \mathrm{ml} / \mathrm{min}$ and the absorbance was recorded at $215 \mathrm{~nm}$.

\section{Gel Electrophoresis}

SDS-PAGE (16\% acrylamide) was performed using a Mini-Protean II system (Bio-Rad, France) according to the method of Schägger and Von J agow (35) with modification (36). Sample preparation consisted of the centrifugal evaporation of $10 \mu \mathrm{l}$ of each culture supernatant before resuspension of the samples in $20 \mu \mathrm{l}$ of sample buffer ( $12 \% \mathrm{v} / \mathrm{v}$ glycerol, $4 \% \mathrm{w} / \mathrm{v}$ SDS, $3 \% \mathrm{w} / \mathrm{v}$ dithiothreitol, $50 \mathrm{mM}$ Tris- $\mathrm{HCl}, \mathrm{pH}$ 6.8). The molecular weight calibration kit PMW (Pharmacia, France) was used and the proteins were visualized by Serva blue $\mathrm{G}$ staining.

\section{I on Spray-Mass Spectrometry (IS-MS)}

Microion spray-mass spectrometry was performed on a Sciex API100 (Perkin-Elmer, France) using a positive mode from 1200 to 3000 a.m.u. with 0.1 a.m.u. steps and a $1 \mathrm{~ms}$ dwell-time. The ion spray needle vol tage was $5000 \mathrm{~V}$ and the orifice plate voltage $+40 \mathrm{~V}$. Infusion was performed at a flow rate of $0.2 \mu \mathrm{l} / \mathrm{min}$. The quadrupole was calibrated with a Perkin-Elmer polypropylene glycol standard solution. Mass spectrometry data were analyzed with the Perkin-ElmerSciex Bio-Multi-View 1.2 software. The average molar masses were calculated using the Perkin-EImer-Sciex Peptide Map 2.2 software.

\section{Edman Degradation}

$\mathrm{N}$-terminal amino acid sequence analysis of proteins was performed by automated Edman degradation using a Perkin-Elmer Procise 494-610A protein sequencer with reagents and methods of the manufacturer.

\section{Thiol Titration}

To quantify the extent of free thiols of the recombinant ASP2, the color reaction using 5,5'-dithiobis (2nitrobenzoic acid) developed by Ellman (37) was performed. Tenfold excess of Ellman's reagent over protein was used and the number of reactive cysteine residues was quantified by following the absorbance at $412 \mathrm{~nm}$.

\section{Shake-Flask Production}

Having identified the best protein-producing pNatAsp2 transformants and determined the optimal growth $\mathrm{pH}$ after induction, intermediate-scale culture was carried out using an incubator Aerotron (Infors, France). Several colonies of a single isolate were used to inoculate $50 \mathrm{ml}$ of BMGY in a $500-\mathrm{ml}$ baffled flask which was then incubated at $29^{\circ} \mathrm{C}, 300 \mathrm{rpm}$, continued for $16 \mathrm{~h} ; 20 \mathrm{ml}$ of this preculture was then used to inoculate 2 liters of BMGY divided between four 3-liter baffled flasks. Incubation at $29^{\circ} \mathrm{C}, 300 \mathrm{rpm}$, was continued for 2 days and at the end of this first phase of fermentation, the cell density reached about $100 \mathrm{~g}$ (wet weight) of cells per liter of culture. The cells were pelleted at $3000 \mathrm{~g}$ for $20 \mathrm{~min}$ at $4^{\circ} \mathrm{C}$ and the supernatant was discarded. The cells were resuspended in a total of 1 liter of BMM medium, pH 7.0, in four sterile 3-liter baffled flasks covered only with one layer of Scrynel NYHC nylon (100- $\mu \mathrm{m}$ mesh, Polylabo, France) and incubation at $29^{\circ} \mathrm{C}, 300 \mathrm{rpm}$, was continued for 7 days. During the induction period, methanol was fed every $24 \mathrm{~h}$ to maintain a concentration of $0.5 \% \mathrm{v} / \mathrm{v}$. About 7 days onward, the level of recombinant protein secreted into the culture medium reached a plateau. 
a

pEAEA $\alpha$ ASP2

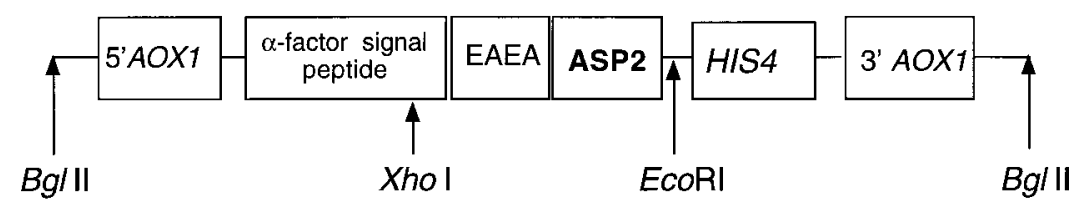

$\mathrm{p} \alpha \mathrm{ASP} 2$

b

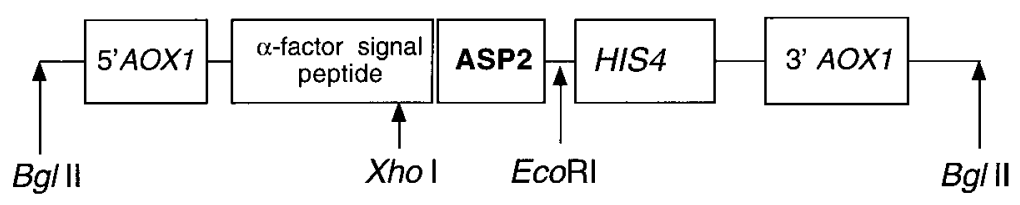

C

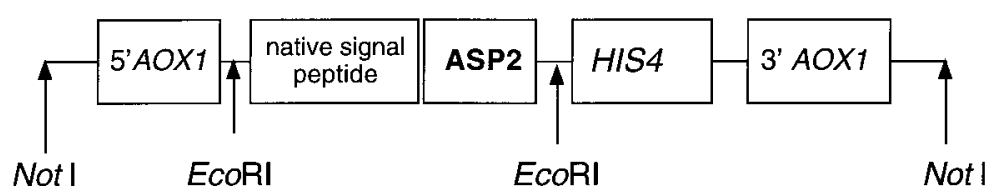

FIG. 1. Construction of the expression vectors for ASP2. The linearized vectors are composed of the AOX 1 promoter (5' AOX1), the mature ASP 2 CDNA, the histidinol dehydrogenase gene (HIS4) for sel ection of transformants and the 3' AOX1 sequence from the AOX 1 gene. (a) The coding mature portion of ASP2 CDNA was cloned between Xhol and EcoRI sites of the expression vector pPIC9 in frame with the $\alpha$-mating prepro-factor signal peptide with the spacer peptide Glu-Ala-Glu-Ala. (b) The coding mature portion of ASP2 cDNA was cloned between Xhol and EcoRI sites of the expression vector pPIC9 in frame with the $\alpha$ mating prepro-factor signal peptide without the Glu-Ala repeats. (c) The coding region of ASP2 CDNA with its native peptide sequence was cloned into the EcoRI site of the expression vector pHIL-D2.

The cells were removed by centrifugation at 10,000 for $30 \mathrm{~min}$ at room temperature and the supernatant was recovered.

\section{Purification of Recombinant ASP2}

ASP 2 has been purified by anion-exchange chromatography. After removing insoluble components from supernatant containing ASP 2 by filtration, the solution was equilibrated with $10 \mathrm{mM}$ Tris- $\mathrm{HCl}$ at $\mathrm{pH} 8.0$ by dialysis for 4 days at $4^{\circ} \mathrm{C}$, using a dialysis tube with 8000 Da cutoff (Servapor, Polylabo, France). The chromatographic conditions have been first determined using a Vydac QAE column (300 VHP, 0.75 i.d. $\times 5 \mathrm{~cm}$, Interchim, France). After loading the dialyzed supernatant, the column was washed with $10 \mathrm{mM}$ Tris- $\mathrm{HCl}$ at $\mathrm{pH} 8.0$ and the elution was achieved using a linear gradient with the same buffer to $0.5 \mathrm{M} \mathrm{NaCl}$ in the first $60 \mathrm{~min}$ and to $1 \mathrm{M} \mathrm{NaCl}$ in the next $20 \mathrm{~min}$. The flow rate was $0.5 \mathrm{ml} / \mathrm{min}$ and the absorbance at $280 \mathrm{~nm}$ was recorded. The purification was performed using two QAE Zeta-Prep (disk 60) disks (Cuno, FLOT, France) using a peristaltic pump with a flow rate of $2.5 \mathrm{ml} / \mathrm{min}$ at room temperature. Disks were equilibrated in 10 $\mathrm{mM}$ Tris- $\mathrm{HCl}$ at $\mathrm{pH}$ 8.0. After loading the supernatant, the disks were washed with the same buffer containing $0.2 \mathrm{M} \mathrm{NaCl}$. The elution was performed with the Tris buffer containing $0.45 \mathrm{M} \mathrm{NaCl}$ and monitored at 280 $\mathrm{nm}$. The fractions containing purified ASP2 were pooled, dialyzed extensively against Milli-Q $\mathrm{H}_{2} \mathrm{O}$, and lyophilized.

\section{RESULTS AND DISCUSSION}

\section{Construction of Expression Vectors and}

Transformation into $\mathrm{P}$. pastoris

To compare the production level and the posttranslational processing in $\mathrm{P}$. pastoris, we constructed three different Pichia expression plasmids. Since it was not certain whether the insect signal peptide could direct secretion of ASP2 from the yeast cell, we also secreted ASP2 with the yeast prepropeptide signal from the S. cer evisiae $\alpha$-mating factor. pEAEA $\alpha$ ASP 2 and $p \alpha A S P 2$ vectors were constructed by inserting the mature coding sequence of ASP2 downstream from the methanolinducible alcohol oxidase (AOXI) promoter between the Xhol and EcoRI restriction sites (Fig. 1). The protein ASP2 was also expressed with its natural honeybee signal peptide using the pHILD2 vector. The full coding CDNA sequence, including the natural signal pep- 

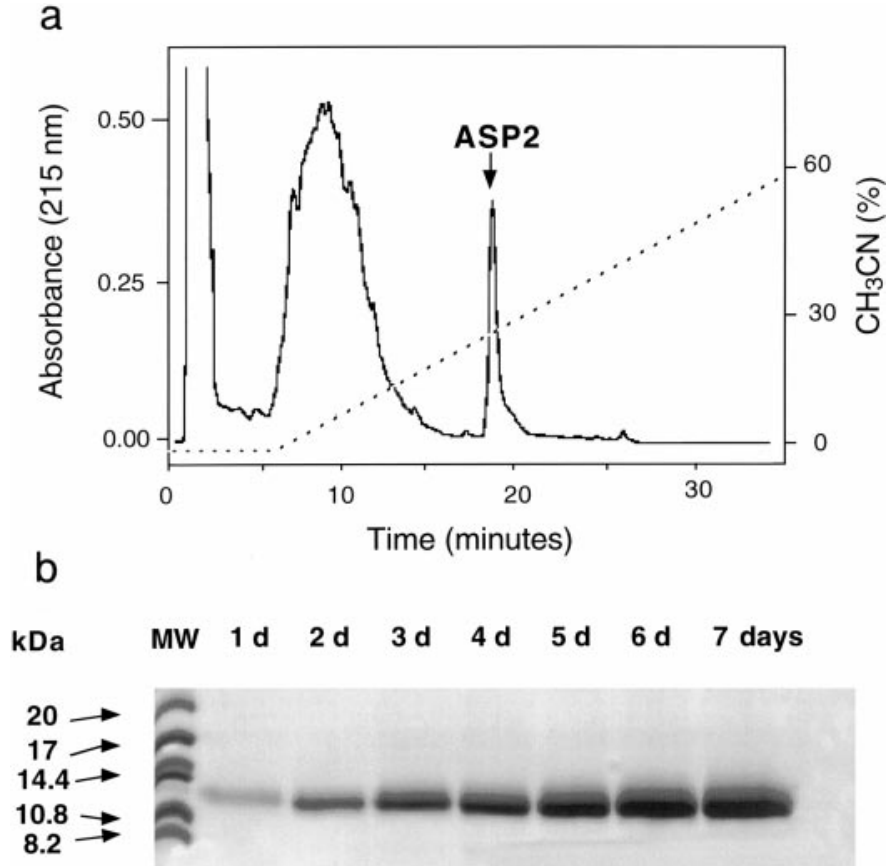

FIG. 2. (a) HPLC analysis of the culture supernatant of the best protein-producing pNatAsp2 P. pastoris transformant. The expression supernatant was chromatographed on an Aquapore (C8) RP 300 column (0.21 i.d. $\times 3 \mathrm{~cm}$, Brownlee, Perkin-Elmer, France) equilibrated with solvent $A\left(0.1 \%\right.$ TFA in $\left.\mathrm{H}_{2} \mathrm{O}\right)$ and eluted with a linear gradient (dashed line) up to $60 \%$ solvent B $(95 \%$ acetonitrile, $5 \%$ $\mathrm{H}_{2} \mathrm{O}, 0.085 \%$ TFA) in 30 min. (b) SDS-PAGE analysis of recombinant ASP 2 secreted by $P$. pastoris using its native peptide signal. Lane 1 shows standard (kit PMW, Pharmacia, France) and lanes 2 to 8 are 10- $\mu$ l aliquots of a 1- to 7-day culture supernatant.

tide and a Kozak sequence introduced by PCR, was inserted at the unique E coRI site flanked by the $5^{\prime}$ and $3^{\prime}$ regulatory sequence of $\mathrm{AOXI}$ promoter giving rise to pNatASP2 vector. For transformation, the plasmids pEAEA $\alpha$ ASP 2 and $p \alpha A S P 2$ were digested with Bgll I and pNatASP2 with Notl to give an integrative fragment containing the ASP 2 CDNA and the HIS4 selectable marker. Approximately $300 \mathrm{His}^{+}$transformants of the GS115 strain were obtained by spheroplasting. Fifty transformants corresponding to $\mathrm{Mut}^{\mathrm{s}}$ phenotypes were isolated. They were grown in the BMGY medium and induced at $29^{\circ} \mathrm{C}$ for 2 days in the BMM medium buffered to $\mathrm{pH}$ 6.0. The higher producing clones were screened by determining the amount of ASP2 secreted in the extracellular medium by automated HPLC (Fig. 2a). The recombinant protein was found to be the major component and el uted at $29 \%$ acetonitrile as the native protein (8). Samples of the expression medium supernatants, taken at various time intervals, were also analyzed by SDS-16\% polyacrylamide gel to determine the optimal induction time. Only the recombinant protein, migrating at about $14 \mathrm{kDa}$, was detectable by Serva blue G staining. The electrophoretic profile (Fig.
$2 b)$ reveals that the protein regularly accumulates up to approximately $0.1 \mathrm{mg} / \mathrm{ml}$ over an expression period of 7 days, while other proteins were present in trace amounts only.

\section{Influence of the Signal Sequence on the Secretion of ASP2 by P. pastoris}

The preprosecretion signal of S. cerevisiae $\alpha$-mating factor has already been used successfully to secrete heterologous proteins in P. pastoris. In S. cerevisiae, it has been noted that the preprosequence of $\alpha$-mating factor is cleaved by the Kex2 gene product in the Golgi apparatus and that the Glu-Ala repeats were further cleaved by the diaminopeptidase encoded by Stel3. It has been observed that the Glu-Ala repeats were not necessary for cleavage by Kex2 but increase the cleavage efficiency. The Glu-Ala-Glu-Ala spacer sequence is subsequently cleaved by the diaminopeptidase Ste13 supposed to leave the protein of interest free of additional $\mathrm{N}$-terminal residues. Therefore, we compared the secretion of the recombinant protein using either the preprosequence of the $\alpha$-mating pheromone of $\mathrm{S}$. cerevisiae with or without the Glu-Ala-Glu-Ala spacer peptide.

Depending on the signal sequence used, N-terminal sequencing of HPLC-purified ASP2 revealed multiple termini as indicated in Fig. 3. Based on the amount of residues released in each cycle of Edman degradation, the percentage of the different $\mathrm{N}$-terminal forms of ASP 2 has been determined. While the prepropeptide of the $\alpha$-factor with the spacer leads to a mixture of heterogenous proteins with multiple $\mathrm{N}$-termini, we found that the preprosequence without the Glu-Ala repeats was efficient for proper secretion and cleavage of recombinant ASP2 in P. pastoris.

To maximize production of ASP2, we also expressed the protein using its own natural leader peptide. The CDNA encoding the native precursor ASP2 was cloned into the EcoRI site of pHIL-D2 and used to transform the yeast cells. Correct processing of the signal sequence was verified by N-terminal analysis of HPLC purified ASP2. The first 12 residues were in agreement with the native ASP 2 amino acid sequence (Fig. 3). The natural insect signal peptide was then revealed to be efficient for proper secretion of heterologous ASP2 in P. pastoris. The best producing clone for each of the three constructions secreted the recombinant ASP2 at a similar level of $150 \mathrm{mg} / \mathrm{liter}$.

\section{Integrity of Recombinant ASP2}

Whatever the construction, a proteolytic C-terminal degradation of the protein ASP2 was also observed, probably caused by extracellular proteases during the fermentation at $\mathrm{pH}$ 6.0. IS-MS showed an amputation of 7 C-terminal amino acids of the protein (data not 
a

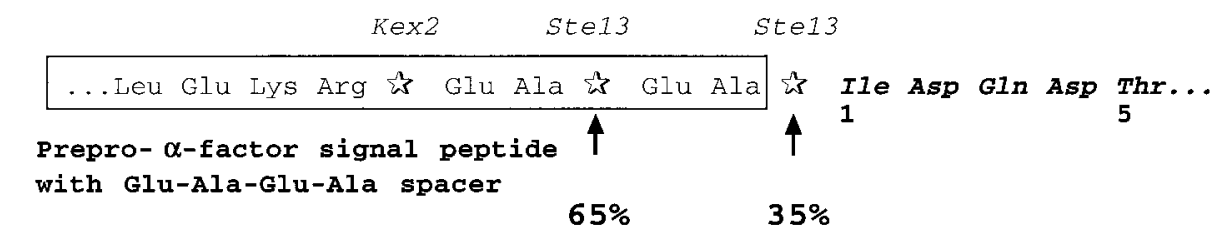

b

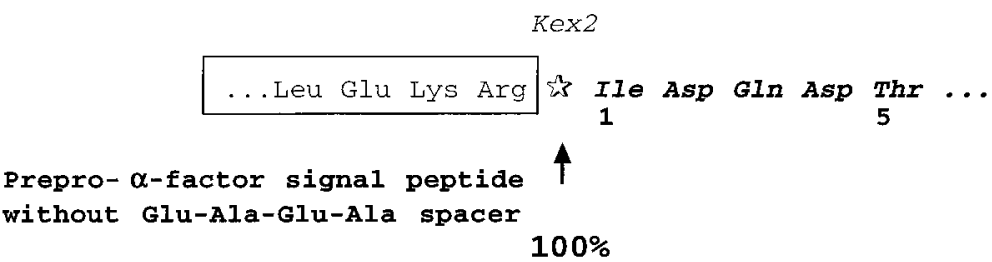

C

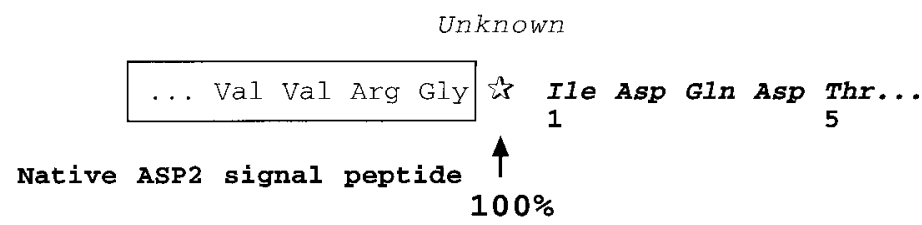

FIG. 3. Determination of $\mathrm{N}$-terminal amino acid sequences of ASP2 secreted using the different signal peptides. The processed $\mathrm{N}$-termini are indicated in bold italics; the removed signal sequences are boxed. The cleavage sites processed by the proteases encoded by Kex2 and Stel3 genes are indicated by a star. (a) $\alpha$-mating prepro-factor signal peptide with the spacer peptide Glu-Ala-Glu-Ala, (b) $\alpha$-mating prepro-factor signal peptide without the Glu-Ala repeats, (c) natural honeybee peptide sequence. The percentages of each secreted ASP2 forms are shown under the arrows indicating the corresponding $\mathrm{N}$-termini.

shown). Proteolysis was nevertheless observed to be affected by the $\mathrm{pH}$ of the culture. Since P. pastoris cells can grow in a wide variety of pHs ranging from 3 to 9, we therefore maintained the culture medium at $\mathrm{pH}$ 7.0-7.5 during cell induction to inactivate the endogenous proteases.

IS-MS on the recombinant protein secreted using its native leader sequence (Fig. 4) showed a predominant peak, together with derivatives corresponding to $\mathrm{Na}$ and $\mathrm{K}$ adducts. The ASP2 mass was found to be $13,695.1 \pm 1.7 \mathrm{Da}$ which is in perfect agreement with the measured molecular mass $(13,695.2 \pm 1.6 \mathrm{Da})$ of the native honeybee protein (8) which is known to not undergo any posttranslational modification other than the cleavage of the 19-residue signal peptide and the formation of three disulfide bridges. The sulfhydryl titration using the method of Ellman confirmed that the three disulfide bridges were indeed formed since a content of approximately 0.1 thiol/protein was measured. The yeast secretion machinery is therefore able to properly process secretory proteins with an insect peptide signal without proteolytic degradation in our culture conditions.

Shake-Flask Production of ASP2 in P. pastoris

The clone with the highest level of ASP2 expression using the natural peptide was chosen for intermediate- scale production in fermentation culture in BMM medium maintaining the $\mathrm{pH}$ at 7.0-7.5. The expression volume has been scaled up to $250 \mathrm{ml}$ per flask and the cell concentration in the expression phase was stable at $100 \mathrm{~g}$ wet weight cells per liter of culture. The purified ASP 2 production reached a level of $150 \mathrm{mg} / \mathrm{liter}$ over an

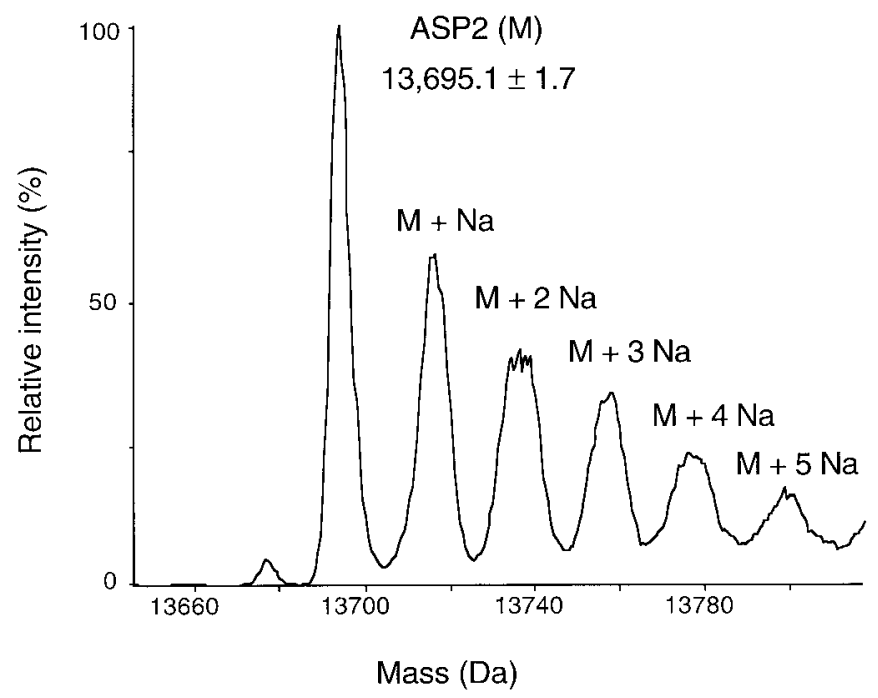

FIG. 4. Reconstructed ion spray mass spectrum of ASP2 with $\mathrm{Na}$ and $\mathrm{K}$ adducts. 


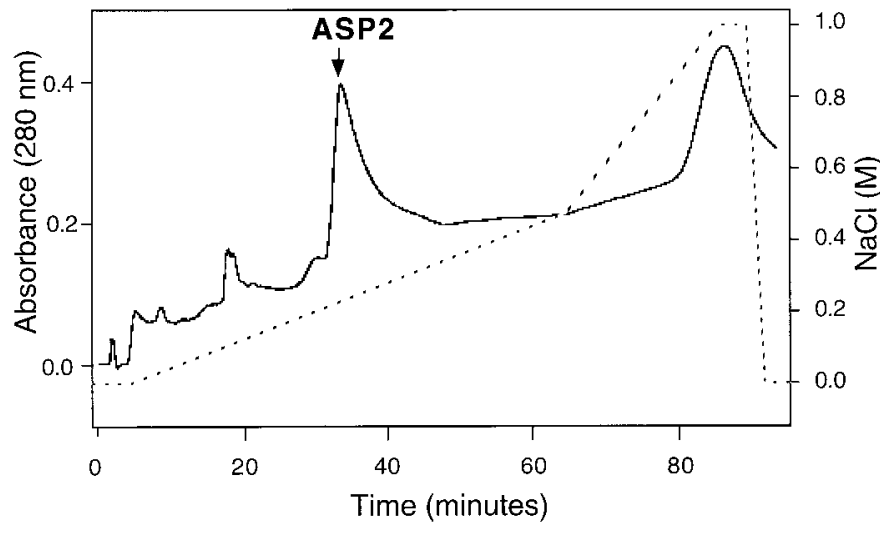

FIG. 5. Chromatogram of ASP2 purification from the cell culture supernatant by ion-exchange chromatography. The expression supernatant was chromatographed on a Vydac QAE column (300 VHP, 0.75 i.d. $\times 5 \mathrm{~cm}$, Interchim, France). ASP2 was eluted with a $\mathrm{NaCl}$ gradient (dashed line) from 0 to $0.5 \mathrm{M} \mathrm{NaCl}$ in the first $60 \mathrm{~min}$ and to $1 \mathrm{M} \mathrm{NaCl}$ in the next $20 \mathrm{~min}$ in $10 \mathrm{mM}$ Tris- $\mathrm{HCl}, \mathrm{pH} 8.0$.

expression period of 7 days. Moreover, efficient expression and secretion could be repeated by reincubation of the isolated cells in minimal medium for 7 more days.

\section{Purification of the Recombinant Protein ASP2}

The high-level secretion of ASP2 from $P$. pastoris facilitated the development of a simple purification method. To determine the chromatographic conditions, after centrifugation at 10,000 for $30 \mathrm{~min}$, the supernatant was clarified by filtration, submitted to dialysis, and then applied to a Vydac QAE column (Fig. 5). Elution was achieved using a linear gradient with 10 $\mathrm{mM}$ Tris $-\mathrm{HCl}$ at $\mathrm{pH} 8.0$ from 0 to $0.5 \mathrm{M} \mathrm{NaCl}$ in the first $60 \mathrm{~min}$ and to $1 \mathrm{M} \mathrm{NaCl}$ in the next $20 \mathrm{~min}$. The protein was eluted as a single peak at relatively high ionic strength $(0.25 \mathrm{M} \mathrm{NaCl})$ in agreement with the calculated pl and migrated as a single 14-kDa species on SDS-PAGE as expected (data not shown).

The purification was performed using two QAE disks equilibrated in $10 \mathrm{mM}$ Tris- $\mathrm{HCl}$ at $\mathrm{pH}$ 8.0. After loading the supernatant, the disks were washed with the same buffer containing $0.2 \mathrm{M} \mathrm{NaCl}$. The elution was performed with the Tris buffer with $0.45 \mathrm{M} \mathrm{NaCl}$. $\mathrm{N}$-terminal sequencing, IS-MS, and reversed-phase chromatography confirmed that the recombinant protein ASP2 was greater than 96\% pure and in perfect agreement with expected features. This purification procedure produced over $150 \mathrm{mg}$ of purified ASP2 from the 1-liter culture supernatant with $85 \%$ overall yield.

\section{CONCLUSION}

The P. pastoris expression system was chosen to express ASP2 because it allows to produce large quantities of soluble disulfide-bonded proteins. This system efficiently secreted ASP2, properly removed the natural signal sequence, and allowed the formation of disulfide bonds, without unexpected processing provided the culture medium was maintained at a $\mathrm{pH}$ ranging from 7.0 to 7.5. The produced protein is very pure and easy to purify since $P$. pastoris secretes only very low levels of its own proteins in the medium. The level of expression that we obtained, approximately $150 \mathrm{mg} /$ liter, is about 100-fold the expression of an insect PBP using baculovirus-infected insect cells (13). To our knowledge, this is the first insect OBP being highly expressed in soluble form with correct disulfide bond formation.

The recombinant protein ASP2 produced in high amounts should allow the screening of specific odorants and the study of their binding properties. In addition, this expression system, easy to scale-up, provides sufficient material for the crystallization trials which are currently under way. Finally, this expression system opens the possibility for site-directed mutagenesis of specific residues to investigate and clearly define the relationships between the structure and the function of this novel protein.

\section{REFERENCES}

1. Pelosi, P. (1994) Odorant-binding proteins. Crit. Rev. Biochem. Mol. Biol. 29, 199-228.

2. Pevsner, J . (1986) Odorant-binding protein: Localization to nasal glands and secretions. Proc. Natl. Acad. Sci. USA 83, 49424946.

3. Pevsner, J ., Hou, V., Snowman, A. M., and Snyder, S. H. (1990) Odorant-binding protein. Characterization of ligand binding. J . Biol. Chem. 265, 6118-6125.

4. Pelosi, P. (1996) Perireceptor events in olfaction. J . Neurobiol. 30, 3-19.

5. Pelosi, P., and Maida, R. (1995) Odorant-binding proteins in insects. Comp. Biochem. Physiol. B 111, 503-514.

6. Kaissling, K. (1996) Peripheral mechanisms of pheromone reception in moths. Chem. Senses 21, 257-268.

7. Feng, L., and Prestwich, G. D. (1997) Expression and characterization of a lepidopteran general odorant-binding protein. Insect Biochem. Mol. Biol. 27, 405- 412.

8. Danty, E., Michard-Vanhée, C., Huet, J .-C., Genecque, E., Pernollet, J .-C., and Masson, C. (1997) Biochemical characterization molecular cloning and localization of a putative odorant-binding protein in the honey bee Apis mellifera L. FEBS Lett. 414, 595-598.

9. Danty, E., Arnold, G., Huet, J .-C., Huet, D., Masson, C., and Pernollet, J .-C. (1998) Separation, characterization and sexual heterogeneity of multiple putative odorant-binding proteins in the honeybee Apis mellifera L. (Hymenoptera: Apidea). Chem. Senses 23, 83-91.

10. Prestwich, G. D. (1993) Bacterial expression and photoaffinity labeling of a pheromone binding protein. Protein Sci. 2, 420428.

11. Du, G., Ng, C.-S., and Prestwich, G. D. (1994) Odorant binding by a pheromone binding protein:active site mapping by photoaffinity labeling. Biochemistry 33, 4812- 4819.

12. Du, G., and Prestwich, G. D. (1995) Protein structure encodes 
the ligand binding specificity in pheromone binding proteins. Biochemistry 34, 8726-8732.

13. Krieger, J ., Raming, K., Prestwich, G. D., Frith, D., Stabel, S., and Breer, H. (1992) Expression of a pheromone-binding protein in insect cells using a baculovirus vector. Eur. J . Biochem. 203, 161-166.

14. White, C. E., Kempi, N. M., and Komives, E. A. (1994) Expression of highly disulfide-bonded proteins in Pichia pastoris. Structure 2, 1003-1005.

15. O'Donohue, M. J ., Boissy, G., Huet, J .-C., Nespoulous, C., Brunie, S., and Pernollet, J .-C. (1996) Overexpression in Pichia pastoris and crystallization of an elicitor protein secreted by the phytopathogenic fungus, Phytophthora cryptogea. Protein Express. Purif. 8, 254-261.

16. Perez, V., Huet, J.-C., O'Donohue, M. J ., Nespoulous, C., and Pernollet, J .-C. (1999) A novel elicitin necrotic site revealed by $\alpha$ cinnamomin sequence and site-directed mutagenesis. Phytochemistry, in press.

17. Gong, J . H., and Clark-Lewis, I. (1995) Antagonists of monocyte chemoattractant protein 1 identified by modification of functionally critical NH2-terminal residues. J . Exp. Med. 181, 631- 640.

18. Cregg, J. M., Vedvick, T. S., and Raschke, W. (1993) Recent advances in the expression of foreign genes in Pichia pastoris. BioTechnology 11, 905-910.

19. Wagner, S. L., Siegel, R. S., Vedvick, T. S., Raschke, W. C., and Van Nostrand, W. E. (1992) High-level expression, purification and characterization of the Kunitz type protease inhibitor domain of protease nexin-2/amyloid $\beta$-protein precursor. Biochem. Biophys. Res. Commun. 186, 1138-1145.

20. Clare, J . J ., Romanos, M. A., Rayment, F. B., Rowedder, J . E., Smith, M. A., Payne, M. M., Sreekrishna, K., and Henwood, C. A. (1991) Production of the mouse epidermal growth factor in yeast: High-level secretion using Pichia pastoris strains containing multiple gene copies. Gene 105, 205-212.

21. Van Nostrand, W. E., Schmaier, A. H., Neiditch, B. R., Siegel, R. S., Raschke, W. C., Sisodia, S. S., and Eagner, S. L. (1994) Expression, purification and characterization of the Kunitz type proteinase inhibitor domain of the amyloid $\beta$-protein precursor like protein-2. Biochim. Biophys. Acta 1209, 165-170.

22. Ridder, R., Schmitz, R., Legay, Y. F., and Gram, H. (1995) Generation of rabbit monoclonal antibody fragment from combinatorial phage display library and their production in the yeast Pichia pastoris. BioT echnology 13, 255-260.

23. Mason, A. B., Woodworth, R. C., Oliver, R. W. A., Green, B. N. Lin, L.-N., Brandts, J . F., Tam, B. M., Maxwell, A., and MacGillivray, R. T. A. (1996) Production and isolation of the recombinant $\mathrm{N}$-lobe of human serum transferrin from the methylotrophic yeast Pichia pastoris. Protein Express. Purif. 8, 119-125.

24. Murphy, K. P., J r., Gagne, P., Pazmany, C., and Moody, M. D. (1998) Expression of human interleukin-17 in Pichia pastoris: purification and characterization. Protein Express. Purif. 12, 208-214.
25. Rosenfeld, S. A., Nadeau, D., Tiradeau, J ., Hollis, G. F., Knabb, R. M., and J a, S. (1996) Production and purification of recombinant hirudin expressed in the methylotrophic yeast Pichia pastoris. Protein Express. Purif. 8, 476- 482.

26. Brankamp, R. G., Sreekrishna, K., Smith, P. L., Blankenship, D. T., and Cardin, A. D. (1995) Expression of a synthetic gene encoding the anticoagulant-antimetastatic protein ghilanten by the methylotrophic yeast Pichia pastoris. Protein Express. Purif. 6, 813- 820.

27. Beall, C. J., Breckenridge, M., Chakravarty, L., and Kolattukudy, P. E. (1998) Expression of human monocyte chemoattractant protein-1 in the yeast Pichia pastoris. Protein Express. Purif. 12, 145-150.

28. Zhu, A., Monahan, C., Wang Z.-K., and Goldstein, J. (1996) Expression, purification and characterization of recombinant $\alpha$ - $\mathrm{N}$-acetylgalactosaminidase produced in the yeast Pichia pastoris. Protein Express. Purif. 8, 456- 462.

29. Barr, K. A., Hopkins, S. A., and Sreekrishna, K. (1992) Protocol for efficient secretion of HSA developed from Pichia pastoris. Pharm. Eng. 12, 48-51.

30. Sreekrishna, K., Tschopp, J . F., and Fluke, M. (1987) Invertase gene (SUC2) of Saccharomyces cerevisiae as a dominant marker for transformation of Pichia pastoris. Gene 59, 115-125.

31. Tschopp, J . F., Svelow, G., Kosson, R., Craik, W., and Grinna, L. (1987) High-level secretion of glycosylated invertase in the methylotrophic yeast, Pichia pastoris. BioTechnology 5, 13051308.

32. Ferrari, E., Lodi, T., Sorbi, R. T., Tirindelli, R., Cavaggioni. A., and Spisni, A. (1997) Expression of a lipocalin in Pichia pastoris: secretion, purification and binding activity of a recombinant mouse major urinary protein. FEBS Lett. 401, 73-77.

33. Morel, N., and Massoulié, J . (1997) Expression and processing of vertebrate acetylcholinesterase in the yeast Pichia pastoris. Biochem. J. 328, 121-129.

34. Digan, M. E., Lair, S. V., Brierly, R. A., Siegel, R., Williams, M. E., Ellis, S. B., Kellaris, P. A., Provow, S. A., Craig, W. S., Velicelebi, G. V., Harpold, M. M., and Thill, G. P. (1989) Continuous production of a novel lysozyme via secretion from the yeast, Pichia pastoris. BioTechnology 7, 160-164.

35. Schägger, H., and von J agow, G. (1987) Tricine-sodium dodecyl sulfate-polyacrylamide gel electrophoresis for the separation of proteins in the range from $1 \mathrm{kDa}$ to $100 \mathrm{kDa}$. Anal. Biochem. 166, 368-379.

36. Sallantin, M., Huet, J .-C., Demarteau, C., and Pernollet, J .-C. (1990) Reassessment of commercially available molecular weight standards for peptide sodium dodecyl sulfate-polyacrylamide gel electrophoresis using electroblotting and microsequencing. Electrophoresis 11, 34-36.

37. Ellman, G. L. (1958) A colorimetric method for determining low concentrations of mercaptans. Arch. Biochem. Biophys. 74, 443450. 